control panel. At the railway station terminus the track runs on to a lift, which operates automatically, rising to the level of the post ofice above. The railway is operated by a three-phase 220-volt, 50-cycle supply. This obviates the need for converter sets or special gear on the motor track for reversing. To reverse, all that is necessary is to interchange the connexions of two phases of the supply.

The motor-truck has two axles, one of which is coupled through gears to a 3.5 h.p. three-phase induction motor, giving the truck a speed of $14.4 \mathrm{ft}$. per sec. The other axle is driven by a 1 h.p. motor for running at low speed $(0.98 \mathrm{ft}$. per sec.). The latter motor is brought into operation at the stations by means of an electro-magnetic coupling controlled by a change-over switch, which is actuated by a roller contacting with a third rail in the station sections. The truck is fitted with a mechanical brake operated by spring force. The order for the whole ins sallation was placed with the Oerlikon Co.

\section{Catalogue of Meteorites}

The British Museum (Natural History) Catalogue of Meteorites was issued in 1923 and a first appendix appeared in 1927. A second appendix, compiled by M. H. Hey, has now been published by the Trustees of the Museum (1940, pp. 136, price 5s. net). It includes particulars of all meteorites described since the appearance of the first appendix up to the end of September 1939. Additions and corrections to some of the earlier entries have been made and a separate list of meteorite craters has been included. It is interesting to note that the catalogue and its appendixes now contain entries for 1,251 reasonably well-authenticated falls, of which 758 are represented in the Museum collections, and for a further 98 'doubtful' and 'paired' falls, of which there are 24 in the collections. Of the 51 'doubtful' falls, a few may not be meteorites, others have never been adequately confirmed or described, and others may have names that may be synonymous with those of falls otherwise recorded. The 47 'paired' falls are pairs or groups of falls which are possibly or probably identical; these have been counted only once in the totals. Falls reported in ancient histories and objects of worship in ancient temples thought to have been meteorites have not been included, except in the case of Jalandhar, which fell in the Punjab in 1621 and was forged into sword blades; in other cases the data are too vague and uncertain.

\section{Extra Fat Allowance for Diabetics}

Mr. Boотнвy, Parliamentary Secretary to the Ministry of Food, has stated in the House of Commons that the Food Rationing (Special Diets) Advisory Committee of the Medical Research Council has advised the Minister of Food that persons suffering from diabetes mellitus should be allowed two extra butter and margarine rations, totalling $12 \mathrm{oz}$, each week. The necessary arrangements for the issuing of the supplementary rations by food executive officers has been made.

\section{Recent Earthquakes}

ON July 30, violent earthquakes occurred on the central plateau of Anatolia. Twelve villages including Peyk were destroyed near Yozgad, the shock also being felt at Ankara, Erzinjan, Tokat, Kayseri, Amasya, Sinop, Istanbul and intervening places. Three hundred people are reported to have been killed and several hundreds of others injured. The epicentre of the shocks appears to have been near Yozgad, which is not far from Erzinjan, the centre of the greatest of all Turkish earthquakes on December 27, 1939 (NATURE, January 6, p. 13). The present shocks cannot be considered as aftershocks of the December 27 earthquake nor are they so intense, but they point to the same general instability of the whole region at the moment, of which all the shocks are the result. It must also be noticed that such a terrific earthquake as that of December 27 would itself give rise to instability which would persist for a considerable time and give rise to earthquake shocks in general not so intense as the original one. Aftershocks of the earthquakes of July 30 were continued on the next day.

An earthquake of considerable severity was experienced in western Hokkaido on August 2. The full extent of the damage caused by the shock is not yet known, but more than a thousand fishing boats were damaged by a huge wave which followed the earthquake, seeming to point to an off-shore epicentre between Hokkaido Island and the mainland of the continent of Asia.

\section{Announcements}

Mr. R. C. Morrison, M.P., has been appointed chairman of an interdepartmental committee to secure greater liaison between the activities of the Ministry of Supply, which is responsible for the salvage campaign, and other sarvices and departments.

THe Adelaide meeting of the Australian and New Zealand Association for the Advancement of Science arranged for August has been postponed. The position will be reviewed when it is considered that conditions may be favourable for the holding of a meeting.

Awards are made from the Sir George Beilby Memorial Fund at intervals determined by the administrators, representing the Institute of Chemistry, the Society of Chemical Industry, and the Institute of Metals. Preference is given to investigations relating to the special interests of Sir George Beilby, including problems connected with fuel economy, chemical engineering and metallurgy. In general, awards are not applicable to workers of established repute, but are granted as an encourage. ment to younger men who have done original independent work of exceptional merit over a period of years. The administrators of the Fund will be glad to have their attention directed to outstanding work of the nature indicated, not later than November 1 . All communications should be addressed to the Convener, Sir George Beilby Memorial Fund, Institute of Chemistry, 30 Russell Square, London, W.C.1. 